\title{
Principles for the pastoral guidance process to women on matters related to human vulnerability and personal integrity
}

\begin{tabular}{|c|c|}
\hline \multicolumn{2}{|c|}{$\begin{array}{l}\text { Author: } \\
\text { Amanda L. du Plessis }{ }^{1}\end{array}$} \\
\hline \multicolumn{2}{|c|}{$\begin{array}{l}\text { Affiliation: } \\
{ }^{1} \text { Unit of Reformed Theology } \\
\text { and the Development of } \\
\text { the South African Society, } \\
\text { North-West University, } \\
\text { Potchefstroom Campus, } \\
\text { South Africa }\end{array}$} \\
\hline \multicolumn{2}{|c|}{$\begin{array}{l}\text { Note: } \\
\text { This article is published in the } \\
\text { section Practical Theology } \\
\text { of the Society for Practical } \\
\text { Theology in South Africa. }\end{array}$} \\
\hline \multicolumn{2}{|c|}{$\begin{array}{l}\text { Correspondence to: } \\
\text { Amanda du Plessis }\end{array}$} \\
\hline \multicolumn{2}{|c|}{$\begin{array}{l}\text { Email: } \\
\text { 12896810@nwu.ac.za }\end{array}$} \\
\hline \multicolumn{2}{|c|}{$\begin{array}{l}\text { Postal address: } \\
\text { Internal Box 147, Private Bag } \\
\text { X6001, Potchefstroom 2520, } \\
\text { South Africa }\end{array}$} \\
\hline \multicolumn{2}{|c|}{$\begin{array}{l}\text { Dates: } \\
\text { Received: } 11 \text { Sept. } 2013 \\
\text { Accepted: } 18 \text { Apr. } 2014 \\
\text { Published: } 06 \text { Apr. } 2015\end{array}$} \\
\hline \multicolumn{2}{|c|}{$\begin{array}{l}\text { How to cite this article: } \\
\text { Du Plessis, A.L., 2015, } \\
\text { 'Principles for the pastoral } \\
\text { guidance process to women } \\
\text { on matters related to human } \\
\text { vulnerability and personal } \\
\text { integrity', HTS Teologiese } \\
\text { Studies/Theological Studies } \\
71(2), \text { Art. \#2068, } 6 \text { pages. } \\
\text { http://dx.doi.org/10.4102/ } \\
\text { hts.v71i2.2068 }\end{array}$} \\
\hline \multicolumn{2}{|c|}{$\begin{array}{l}\text { Copyright: } \\
\text { C) 2015. The Authors. } \\
\text { Licensee: AOSIS } \\
\text { OpenJournals. This } \\
\text { work is licensed under } \\
\text { the Creative Commons } \\
\text { Attribution License. }\end{array}$} \\
\hline \multirow{2}{*}{ 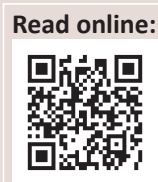 } & \\
\hline & $\begin{array}{l}\text { Scan this QR } \\
\text { code with your } \\
\text { smart phone or } \\
\text { mobile device } \\
\text { to read online. }\end{array}$ \\
\hline
\end{tabular}

Through the centuries, women from all over the world remain vulnerable to their social status. In some developed countries the situation has improved, but there are many countries where it is still unbearable. United Nations Educational, Scientific and Cultural Organization (UNESCO) aims to assist in this regard by addressing ethical issues pertaining to medicine, life sciences and related technologies as applied to human beings with consideration of women's social, legal and environmental dimensions. Yet pastoral counsellors on ground level are confronted with the need for assistance to women who suffer because of this exploitation. Therefore, the aim of this article is to focus on biblical principles that can serve as anchors to guide women regarding their human vulnerability and personal integrity when they experience suffering and hardship. The challenge facing the pastoral counsellor is to guide women to accept the reality of their situation within a certain framework, to adequately deal with this and, in spite of overwhelming emotions, continue to grow in personal integrity and healing.

\section{Introduction}

Through the centuries, women from all over the world still remain vulnerable to their social status. In many developed countries the situation has improved but there are numerous countries where it is still unbearable. South Africa is no exception when it comes to violence and abuse against women and children. On 13 February 2014, President Jacob Zuma delivered his sixth State of the Nation Address in Parliament and emphasised that one of the key focus areas of crime fighting is to eradicate violence against women and children. ${ }^{1}$ Sadly, 'violence against women in South Africa remains rampant, irrespective of human rights' and focussed 'laws passed by government' (Mogale, Burns \& Richter 2012:580). Violence against women affects all communities and takes on many different forms; it ranges from violence at the level of intimate relationships like domestic violence and pervasive levels of coercive sex, to violence that occurs in the public sphere, including the trafficking of women and witch burning (Gumede 2011:38). The latter is a form of active violence, but passive violence like discrimination and manipulation is also very relevant. United Nations Educational, Scientific and Cultural Organization (UNESCO) aims to assist in this regard by addressing ethical issues pertaining to medicine, life sciences and related technologies as applied to human beings with consideration of women's social, legal and environmental dimensions. Yet pastoral counsellors on ground level are confronted with the need for assistance to women who suffer because of this exploitation. Therefore the aim of this article is to focus on biblical principles that can serve as anchor points to guide women with regard to their vulnerability and personal integrity when they experience suffering and hardship. The research question is 'What can women learn about their own vulnerability and integrity during suffering and hardship'? The research methodology is based on scholarly literature and is presented by investigating the link between human vulnerability and personal integrity. It also discusses these results in relation with important principles for the pastoral guidance process. The researcher operates from a reformed point of departure throughout in the usage and application of the Scripture.

\section{Human vulnerability and personal integrity}

The first part of the article gives a description of human vulnerability and personal integrity, as well as an investigation of the relation between the two. Although the concepts vulnerability and integrity do not seem related on face value, there is an inherent link. Human beings are vulnerable in certain situations, and a person's integrity is challenged in dealing with or avoiding the realities of a situation. The entire system of society is based on certain moral and ethical 1.Two laws had been promulgated by the government, namely the Domestic Violence Act No. 116 of 1998 and the Criminal Law for
Sexual offence and related matters Act 32 of 2007 . These attempts were extended in 2004 with the establishment of the Ministry for Women, Children and Persons with Disability (Brendall 2010:103) 
aspects that are determined by a person's frame of reference or angle of approach.

A report by UNESCO (Semplici 2013:n.p.) includes a declaration on the principles of respect regarding 'human vulnerability and personal integrity'. Article 1 of this report states that UNESCO is committed to address the ethical issues surrounding medication, life sciences and related technologies as applied to individuals, with consideration to 'their social, legal and environmental dimensions' (Semplici 2013:9). Article 8 links this commitment to respect for personal integrity and the necessity of protecting vulnerable individuals or groups (Semplici 2013:9). According to the report, 'there is an integral link between respect for a person's integrity and dignity, on the one hand, and on the other hand, his or her vulnerability' (Semplici 2013:9). The report states that humanity implies vulnerability (Semplici 2013:13). Every human being is exposed to the risk of physical, psychological or spiritual wounds occurring at some stage during their life. Vulnerability therefore remains an unavoidable aspect of life and sometimes even gives shape to mutual human relationships. Vulnerability implies that human beings are not always able to fully protect themselves on all levels of humanity (e.g. in times of sickness or in warzones). Although certain groups are vulnerable because of their social status (e.g. women and children), an individual's vulnerability is determined by the situation. ${ }^{2}$

In most cases vulnerability can be identified reasonably easily, because something fundamental in the person's life is affected (e.g. his or her dignity, human rights or fundamental freedom). When a person's fundamental rights are negatively affected, his or her identity or human dignity is harmed. The preservation of integrity implies protection against this form of humiliation. According to Louw (2005:17), there is a profound religious motif in the protection of human dignity. He explains that in the care of human souls (cura animarum) and in the practice of pastoral counselling, there should be a functional-hermeneutical approach. In other words, the understanding of being human occurs within relationships and support networks (e.g. the relationship between believers). He argues that in all circumstances it is the understanding of the approach of both God (i.e. the view of God) and other people (i.e. the view of man) that determines the integrity and human dignity of a person.

UNESCO lists the possible things that may contribute to human vulnerability:

- poverty and inequality with regard to income, social circumstances, education and access to information

- gender discrimination

- cases of substantial limitation of human freedom, for instance, persons that are imprisoned

- relational hierarchies

2.UNESCO categorises women and children as especially vulnerable (Semplic 2013:09).
- marginalisation on several terrains, for instance, immigration, as well as ethnic and racial minorities

- inequalities in human rights

- abuse of resources in developing countries

- war situations

- negative consequences of human reactions

- impact of natural disasters (Semplici 2013:15).

This list of possibilities clearly reveals that the consequences of suffering sometimes result from the human actions towards the self and sometimes humans are entirely the victims because of someone else's reactions. According to Milacci (2011:43), humans are vulnerable because they are human, and for this reason suffering is not new or unique. Scripture describes suffering as the consequence of the Fall of Man (Gn 3) and universal to human conditions (see Job 5:7; Milacci 2011:44). This often causes crises of faith and forces the individual to reconsider his or her view of life, man and God. During times of hardship the individual is confronted with questions like 'What do I believe?', 'Who am I?', 'Where do I fit in?' and 'Who is God?' If such an individual does not have certain fundamental foundations and the ability to judge the situation or deal with the events, it can have catastrophic consequences.

According to Remen (2006:105), the origin of human suffering and hardship is often based on the confusion between illusion and reality. Yet, suffering and hardship can save a person from illusions and a false sense of security. Hardship compels humans to make new discoveries and to learn new things. Remen (2006:118) also links suffering to wholeness or integrity. The influence of suffering which leads a person to personal integrity is not only a Christian principle of faith; it also forms part of almost all religious traditions. James 1:2-5 and Hebrews 12 are indicative of the positive consequences suffering can have for believers.

According to Cloud (2006:31), integrity is ultimately more than just the morality and ethical principles society is based on. Although these two aspects are important, integrity also highlights the person's character and identity. Cloud (2006:31) describes it as 'a state of being whole and undivided; a condition of being unified, unimpaired or sound in construction; internal consistency or lack of corruption'. The Latin word integritas means 'intact, integrate, integral, entirety; the whole thing is working well, undivided, integrated, intact and uncorrupted' (Cloud 2006:32). Therefore, to be a 'whole' person or a person with integrity does not mean to be perfect in the sense of never making mistakes or having no shortcomings. It means that the person is the human he or she is meant to be, has self-knowledge of his or her abilities and gifts, and uses this knowledge to adapt to the realities of life and to react with full honesty. Neither the individual's vulnerability, nor its negative consequences are denied, but accepted as part of reality. Louw (2005:101) emphasises the fact that understanding does not imply explanation, but rather the development of knowledge to cope with reality. It implies the ability to see the rationale for suffering and hardship, and to pursue a certain attitude that 
can contribute to a constructive process of growth in integrity to a life founded in the certainty of God's love.

A person's expectation of life is important in his or her understanding of reality. A person functions in, and evaluates the world from, within a certain framework, and as a result his or her basic presuppositions are shattered when suffering and hardship occurs. One such presupposition is that of invulnerability, that is, that one will be released from suffering and hardship. When suffering and hardship do occur, the world is inevitably observed as an unsafe place. The result is that individuals tend to isolate themselves from society. Pastoral guidance in such a case will entail that the person has to realise his or her own vulnerability (Coetzer 2003:13). Our immediate response to suffering and hardship is to react with either anger or self-pity and guilt. However, it can set one free from preconceptions and furnish the individual with the ability to reach out to others. A person's ability to grow as a result of suffering and hardship is largely determined by aspects like culture, context, relationships and support networks, overall emotional state and intellectual capacity (Louw 2005:101).

Louw (2005:104) divides reactions on suffering and hardship into two groups, namely inappropriate and appropriate behaviour.

\section{Inappropriate behaviour}

Although the responses in this category may be valid in the actual situation, it has the possibility to influence human dignity (i.e. wholeness) in a negative way. Such wounding can lead to regression and ultimate disorientation that, in turn, cause confusion. The confusion can become disintegrated; as a result, the person loses all meaning and interest in life. Inappropriate reactions include the following:

- Avoiding suffering and hardships - an attempt to evade suffering.

- Denying suffering and hardship - a refusal to deal with it.

- Regression during suffering and hardship - to fade away and relive the past when life was more uncomplicated.

- Capitulating in suffering and hardship - to fall into selfpity.

- Trying to neutralise suffering and hardship - to think that it is not so bad and to quietly hope for a surprise (Louw 2005:104).

\section{Appropriate behaviour}

Appropriate behaviour shows maturity, responsibility and integrity. Applicable reactions include:

- Internalisation - to identify suffering and hardship as part of reality and to react accordingly.

- Pro-active action - to accept suffering and hardship as a learning curve and to investigate alternatives.

- Accommodation - to show inner surrender and acceptance. Change what is possible, and accept the unalterable as reality without further damage.
- Goal formulation ${ }^{3}$ - to set goals during suffering and hardship can help the person to start dealing with it. Such goal formulation implies clarity about different possible options, own abilities and boundaries, as well as the possible means and support systems that are needed (Louw 2005:104-105).

In light of the above, the following deductions are significant:

- Integrity indicates the probity and complete honesty of a person. It shows the wholeness of a person and his or her capacity to integrate his or her total humanity in order to react to the realities of life, to deal with these realities and to transform them into opportunities for growth.

- Humanity refers to vulnerability. Every person is inherently vulnerable and runs the risk of being hurt somewhere along the course of his or her life, that is, on spiritual, social, psychological or physical domain.

- Some people are always vulnerable due to their social status, for instance women and children who are highlighted as being exceptionally vulnerable. Other groups are only vulnerable in certain situations.

- When a person experiences suffering and hardship, he or she is often forced to distinguish between reality and illusion. This leaves the person with a choice of how he or she wants to react to the suffering. Will it influence him or her negatively, or will the situation be transformed into an opportunity for growth?

- When integrity is defined as the ability to accept the realities of life and to deal with them, it guides the person to grow and live a meaningful life filled with hope even in times of suffering and hardship.

- Suitable reactions to suffering and hardship lead to awareness and understanding of the circumstances, even though there are not necessarily answers to all the questions in life. It has to do with the courage and hope that enable people to transform the question mark in such a way that it ultimately becomes an exclamation mark.

\section{Principles for pastoral guidance to women regarding their vulnerability and personal integrity}

In the second part of the article, the focus is on the pastoral guidance to women regarding their vulnerability and personal integrity when suffering and hardship are experienced. König (2002) designates that subjecting a topic such as suffering and the providence of God is very difficult, because:

$[W]$ ith the doctrine of the providence we are placed squarely within reality, or rather, in the most broken and hurt part of reality. It is people who suffer, people who are disillusioned and people who feel that they have reached the end of their life,

3.According to Louw (2005:105), a constructive goal usually has a verb (i.e. it describes an action), a time (i.e. it describes the duration), a place (i.e. it describes the location and circumstances), a means (i.e. it describes the instruments of persons that are used or approached), a method (i.e. it describes the 'how'), a support system (i.e. it describes who can possibly help), a source (i.e. in the Christian context it refers to Scripture, prayer and the sacraments), a possible reward (i.e. this indicates a pleasant reward when the goal is achieved), and a description of a monitoring system. 
who ask questions. Why is it so difficult to write about this in a meaningful way? ... Is our faith a stranger to reality? [Author's own translation] (p. 14)

König (2002:13) also mentions that he has often experienced how "well-sounding theories on "evil" and "sin" make one's hair stand on end when applied to concrete suffering'. It seems as if church members are often ignorant when dealing with and supporting people who are suffering. The consequence is that biblical texts are used as 'plasters'. Peterson (2009:464) warns that the church, either by its silence or instruction, too often advises these physically or emotionally battered women to stay in the abusive relationship and to 'forgive and forget'. Denial and/or silence in religious communities in terms of violence against women, not only immobilise the victims, but also encourage the behaviour of the perpetrator. This approach leaves the victim with more questions, uncertainty and feelings of guilt. Wittmer (2008:24) argues that several of the modernday approaches lead to a supplanting of Scripture as the source of truth, consequently leaving room for uncertainties in the pastoral guidance process. This arbitrariness in fact deprives the woman, already weighed down by hardship and suffering, of her anchors. Often she is guided to make sense of life, rather than to discover God's truth; to act in a manner acceptable to society rather than to be a true follower of Christ, and to come to self-acceptance rather than to live from the certainty of God the Father's unconditional love in Christ (Breed 2013:226). When considering this statement, the subtle shift in emphasis becomes clear.

Through the ages much has been written on human suffering and hardship, and God's role in it. The aim of this article is not to become involved in this discourse, but to consider some principles for the pastoral guidance to women who suffer, whilst reflecting on human vulnerability and personal integrity. In the process of pastoral guidance, the challenge to pastoral counsellors is to guide women to discover God's truth in difficult life situations, to be a true follower of Christ, and to live from the certainty of God the Father's unconditional love in Christ. If this occurs, there will be growth in personal integrity despite vulnerability and suffering. Pastoral discussion is an important part of this process. According to Sibcy (2011:101), conversation is fundamental to healing, because it becomes the entry point for the pastoral counsellor to gain access to the woman's life. However, many people do not have the ability or are not willing to communicate effectively, mainly due to their own preconceived ideas (Collins 1998:33); for example, they often feel that such overwhelming emotions and the need for pastoral guidance are indications of a personal or spiritual failure. Peterson (2009:454) concludes that shame, embarrassment, guilt and fear have kept and continue to keep many women from revealing their difficulties. Barriers in communication are largely overcome by an attitude of warm-heartedness, truthfulness and empathy. During the conversations these women are guided towards insight and the power of distinction regarding their circumstances by acknowledging and addressing existing symptoms and by linking this with the possible cause for the person to deal with the problems by means of cognitive restructuring ( $\mathrm{Rm}$ 12:1-2). Cognitive restructuring helps women deal with the wounding and growth towards integrity.

Breed (2013:227) aptly states that the pastoral counsellor's view of man and God greatly influences the pastoral guiding process and distinguishes four points of departure:

- Mankind is a being in conversation.

- Man is an imperfect being that can be renewed by God.

- Change in man is closely linked to his or her thoughts or convictions.

- Change in a person's thoughts and behaviour is the result of knowledge of God.

In my view, these four points of departure can be summarised in two words, namely covenant relationship. The certainty of a covenant relationship with God offers a safe space where growth in integrity can take place. Postma (1980) describes the covenant relationship between God and man as follows:

The covenant of grace is the special form of the salvational order in which the Triune God commits to be a Father, Saviour and Sanctifier of the believers and their descendants and where they commit to be his property and to serve Him, so that they can only be lost to this covenant through lack of faith and disobedience. [Author's own translation] (p. 9)

The covenant relationship between God and mankind gives certainty to believers that God is committed to this relationship, and consequently, a safe space is created where these women can grow spiritually and emotionally to maturity in the relationship. Wright (2003:17) points out to pastoral counsellors that, although it is important to refer to Jesus' earthly ministry as an example of interaction with other people, it is not so much the techniques that matter, but the fact that Jesus' relationship with people is central to his actions and healings. Knowing that God becomes an anchor in the lives of these women keeps them strong in the face of suffering and hardship. When they worship God for who he is, this will lead to changes in their thoughts and behaviours. This means that the woman does not use her relationship with God to avoid suffering and hardship through spiritualisation, but rather uses her relationship with God as the source of her choice of action (Louw 2005:104-105). Breed (2013:232) indicates that the meaning of the Father's love and the grace of Jesus Christ in communion with the Spirit should be applied to the lives of these women to form the foundation from which change can occur. The pastoral guidance conversation not only occurs on a horizontal level between people, but also vertically with God. It is an important certainty for women to know that they can enter into a conversation with God and that he will assist in their process of healing. Du Plessis (2007:2) defines prayer as the foundation within the framework of the covenant relationship between God and these women where intimate conversation takes place. The Holy Spirit is described as the facilitator of this conversation when women pray to God in trust and faith. Breed (2013:228) emphasises the fact that mankind has been created in the 
image of God and acts as God's representative on earth, and this presupposes communication between God and mankind. According to Baloyi (2012:3 of 6), it is impossible for believers to bear the image of God without a relationship with him. It is indeed in their relationship and communication with God that women can find the foundation for their human dignity and identity.

A growth in integrity is ultimately a process during which the emotionally and spiritually wounded woman can gain knowledge and understanding of suffering and hardship with the help of the Holy Spirit as well as the effect of the negative results of it. This is accompanied by the healing of the painful memories and the reprogramming of negative thought patterns (Du Plessis 2007:3). Women do not have to be a victim of their circumstances because they have the capacity to choose how they want to react. This develops into the applicable processing of vulnerability (Louw 2005:104-105) is referring to. Applicable behaviour is ultimately determined by these women's emotional and spiritual maturity, responsibility and integrity. Negative events do not have to have a negative influence on women's integrity. Women can use these events as a phase to gain valuable experience in their attempt to attain perfection in Christ (Ja 1:2-3; 2 Pt 1:5-12), which will contribute to their human dignity.

According to Vorster (2011:3), there are three revelational doctrines in particular that concern human dignity, namely man as the receiver of the Holy Spirit and of the gifts of the Holy Spirit, man as the steward of creation, and man as the inheritor of the new earth. This will put these women's vulnerability into a perspective of eternity, which will lead to growth in their personal integrity. This new perspective helps women to integrate their total humanity in order for them to react to the realities of life, to process it, and to transform it into opportunities for growth by formulating goals. ${ }^{4}$ The perspective of eternity indicates the eschatological character of the process of pastoral guidance. Moltmann (1967:16) shows that believers find their hope in Jesus Christ through the kingdom of God, which is already present in the existing circumstances of the world, although only partially.

Therefore, women can have hope in their present circumstances because their hope is anchored in God (Heb 6:10-20). Vos (2007) describes hope with the following metaphor:

Hope is like a lily in muddy water. The lily flowers in this water and like the lily, hope grows in distressful and muddy circumstances. Hope can exist in mud and can live off beauty. But hope also reminds us of our frailty. (p. 11)

This metaphor aptly portrays the process of pastoral guidance. Regardless of suffering and hardship, these women make the ultimate choice to 'flower' again. However, this growth in integrity is only possible by means of deep

4.See Louw's remarks on this in footnote 3 . trust in and obedience to God, which inspire them to deal with the circumstances courageously.

According to the reformed theology, God reveals himself in nature (Rm 1:20; Ps 19:2), the written Word (1 Tm 3:1617), and the Word that became flesh (Jn 1:1; 1:14). Firstly, the revelation of God in nature is described as the general revelation. This prevents women from standing innocently in front of God should they not know him or the truth. Secondly, the confession states that the Bible fully includes the will of God, as well as a total knowledge for the salvation of believing women (Jooste 2011:44). Thirdly, these women know God through the Word that became flesh. Christ is, as the Word of God, the key to knowledge of God (Jooste 2011:45) through his role in working with suffering and hardship. As mentioned earlier, Louw (2005:101) indicates that understanding is not explanation, but rather the developing of perspective and insight into reality. This means the ability to recognise God's sovereignty and to know that there are certain things unfathomable to mankind. However, the relationship between suffering and hardship should be recognised, and one should strive towards a certain viewpoint that can contribute to a constructive process of integration, goal setting and giving meaning.

In John 14:12-21, the promise of the Holy Spirit is given; the term 'reveals' is of exceptional importance. Louw and Nida (1988) describe the term as to:

$[B]$ ring something to full knowledge and familiarity through revelation; to know something, to know, to explain, to bring to light; to make something clearer; to know something by means of Divine revelation and to bring something to light that was previously unknown or incomprehensible. (p. 338)

The knowledge of the Word offers a new perspective on reality for these women - for them to live with inner peace. They will be able to think and plan anew. Therefore the women have the ability now to regain their inner peace by dealing with their suffering and hardship.

From these principles for the pastoral guidance of women regarding human vulnerability and personal integrity, it is now possible to concur with Breed's (2013) definition of pastoral science:

Pastoral science entails the scientific study of the Word of God, the human being, and reality in other applicable subject disciplines. The aim is to develop Biblical principles and to design and apply a pastoral model that can lead believers to a deeper knowledge of God and themselves through the powerful work of the Holy Spirit. This in turn leads to a growth in faith that will enable believers to deal with the crises in life with calm and to the glory of God and in a manner that result in a growth in faith within the community of saints. [Author's own translation] (p. 240)

In conclusion, the distinction can be made that the Word of God remains the primary source of the process of pastoral guidance, because this is the way God reveals himself to 
mankind. It implies that these women can know God to the extent he reveals himself to them. They can experience a growth in integrity in as far as they recommence themselves to God's revelation. Ultimately they have a choice between being handicapped by the suffering and hardship, or being renewed by it. Pastoral science also includes the scientific study of human beings, reality and the applicable subject disciplines. Integrity has already been defined as the ability to interact with reality. These women are challenged to change the changeable and to accept the unchangeable. Acceptance implies certain adjustments in their lives. Circumstances will no longer have any negative influence on them. To get to this point, the field of pastoral care works with other subject disciplines, for instance social work, psychiatry and psychology. When these women apply and live according to biblical principles, it leads to forgiveness, healing and renewal. Although they cannot always explain God's measures, they are assured of his love and guidance in their lives. The pastoral counsellor is ultimately only the instrument in God's hands for the recovery of these women.

\section{Conclusion}

Humanity implies vulnerability. Humans are not always able to protect themselves in all circumstances. Injustices to their human dignity can potentially leave them with many unanswered questions and scars. Women are considered more vulnerable due to their social status and other reasons mentioned earlier. The challenge to the pastoral counsellor is to guide these individuals to accept and work through their suffering - despite the presence of overwhelming emotions - and to grow in personal integrity towards healing. These women should grow in God's redeeming love and grace to live their new-found freedom entirely with courage and determination. It is therefore possible to derive that suffering and hardship can have certain positive results including the discovery of new possibilities, the development of inner strength and spiritual growth, as well as new appreciation for life and relationships with other people. The challenge to the pastoral counsellor is to guide women towards this point. When a woman struggles with human vulnerability that seemingly has no apparent answers, it is indeed a dark time in her life, but the difficulties should not have a negative effect on her by destroying her identity and dignity. Although the pain and sadness can potentially be overwhelming, the pastoral counsellor should guide this woman in her search for meaning. According to Coetzer (2006:115), it is ultimately a change from the question 'Why did this happen?' to 'Lord, who are You really?'.

\section{Acknowledgements Competing interests}

The author declares that she has no financial or personal relationship(s) that may have inappropriately influenced her in writing this article.

\section{References}

Baloyi, E.M., 2012, 'The use of Imago Dei as a pastoral healing vision against women killings in the South African context', Verbum et Ecclesia 33(1), 1-6. http://dx.doi. org/10.4102/ve.v33i1.703

Breed, G., 2013, 'Metateoretiese vertrekpunte ten opsigte van wetenskaplike navorsing in pastoraal', in F. de Wet \& B.J. de Klerk (eds.), Met die oog op God, bl. 225-250, Potchefstroom Theological Publications, Potchefstroom.

Brendall, C., 2010, 'The domestic violence epidemic in South Africa: Legal and practical remedies', Women's Studies 39(1), 100-118. http://dx.doi. org/10.1080/00497870903459275

Cloud, H., 2006, Integrity: The courage to meet the demands of reality, Harper Collins Books, New York.

Coetzer, W.C., 2003, Traumaberading: Studiegids, Noordwes Universiteit, Potchefstroom.

Coetzer, W.C., 2006, Belangrike riglyne vir die beradingsproses: Studiesgids, Noordwes Universiteit, Potchefstroom.

Collins, G.R., 1998, Christian counselling: A comprehensive guide, NavPress, Colorado Springs.

Du Plessis, A.L., 2007, 'Die rol van gebed by die proses van innerlike genesing: 'n Pastorale studie', PhD verhandeling, Dept. Teologie, Noordwes Universiteit.

Gumede, Z., 2011, 'Abuse is no secret in South Africa', Nursing Update, November, 38-39.

Jooste, C., 2011, 'Sola Scriptura: Die skrifbeskouing in die Gereformeerde Kerke van Suid-Afrika sedert 1959 - 'n Dogmaties-historiese ondersoek', MTh verhandeling, Dept. Teologie, Noordwes Universiteit.

König, A., 2002, God, waarom lyk die wêreld so? Kan ons sê God is in beheer?, Lux Verbi, Wellington.

Louw, D.A., 2005, Ratwerke van die menslike siel: Oor volwassenheid en lewensvaardighede, Sun Press, Stellenbosch.

Louw, J.P. \& Nida, E.A., 1988, Greek-English lexicon of the New Testament based on semantic domains, UBS, New York.

Milacci, F., 2011, 'Theology of suffering', in T. Clinton \& R. Hawkins (eds.), The popular encyclopaedia of Christian counselling, pp. 42-44, Harvest House Publishers, Eugene.

Mogale, R.S., Burns, K.K. \& Richter, S., 2012, 'Violence against women in South Africa: Policy position and recommendations', Sage Publications 18(5), 580-590.

Moltmann, J., 1967, Theology of hope, SCM Press, London.

Peterson, E., 2009, 'Addressing domestic violence: Challenges experienced by Anglican Clergy in the Diocese of Cape Town, South Africa', Social work and Christianity 36(4), 449-469.

Postma, D., 1980, Prediking en verbond, Calvyn Jubileum Boekefonds, Potchefstroom.

Remen, R.N., 2006, Kitchen table wisdom: Stories that heal, Riverhead Books, New York.

Semplici, S., 2013, The principle of respect for human vulnerability and personal integrity: Report of the International Bioethics Committee of UNESCO, UNESCO, France.

Sibcy, G., 2011, 'Interviewing', in T. Clinton \& R. Hawkins (eds.), The popular encyclopaedia of Christian counselling, pp. 101-103, Harvest House Publishers, Eugene.

Vorster, J.M., 2011, Menswaardigheid, versoening en vergiffenis, Potchefstroom Theological Publications, Potchefstroom.

Vos, C.J.A., 2007, 'Preaching as a language of hope', in C.J.A. Vos, L.L. Hogan \& J. Cilliers (eds.), Preaching as a language of hope, pp. 5-13, Protea Book House, Pretoria.

Wittmer, M.E., 2008, Don't stop believing: Why living like Jesus is not enough, Zondervan, Grand Rapids.

Wright, N.H., 2003, The new guide to crisis and trauma counselling: A practical guide to ministers, counsellors and lay counsellors, Regal Books, Ventura. 